\title{
Yunus'un Tasavvuf Anlayışının Kurucu Unsurları: Ezelî İnsan ve Kadim Tanrı Arasında Aşka Dönüşen İman
}

\author{
Constituent Elements of the Șūfi Understanding of Yūnus Emre: Faith That Turns into \\ Love Between Primordial Man and Eternal God
}

\author{
Ekrem Demirli* ${ }^{*}$
}

\section{Öz}

Yunus Emre'nin (ö. 720/1320 [?]) şiiri üzerinde dilciler ve edebiyat tarihçileriyle başlayan bilimsel çalışmalar son zamanlarda artan bir ilgiyle tasavvuf akademisyenleriyle de devam etmektedir. Yunus Emre'nin tarihsel şahsiyeti hakkındaki bilgilerin menkıbeler ile örülmüş olması "gerçeklik" arayışını tezyif eden en önemli nedenlerden birisidir. Hakkında anlatılan ilk hikâye tasavvuf tarihinin en tanınmış menkıbelerinden birisini teşkil etmiş, buğday ve himmet şeklinde ortaya çıkan ikilem dünyevilik ile uhreviliği anlatan en nefis sembollerden birisi olmuştur. Hayat hikâyesindeki bu belirsizlik kadar onun şiiri ve eserleri üzerinde de belirsizlik ortaya çıkmış, önemli bir kısmına kendisinin katkı sağlamış olduğu anonim anlatımın içinde bireysel varlığı fark edilemez hale gelmiştir. Yunus'un "Yüz bini birdir dervişlerin, araya ağyar gerekmez" dediği gibi, Yunus bütün dervişler cemaatinin parçası sayılarak özgünlüğü dikkate alınmamıştır. Buna mukabil Yunus bir umum isim haline gelerek birçok şairin özendiği ve taklit ettiği, hatta ismini kullandığı başat isim olmuştur. Bir düşünür veya şair üzerinde çalışma yapmak onun düşünceye neyi kattı̆ını hesaba katarak bireysel yaratıcılığını keşfetmeyi iktiza eder, en azından böyle bir amaç olmalıdır. Bu makalede Yunus'un bir düşünce geleneği dâhilindeki yerini, onun düşüncesini şekillendiren tasavvufun Yunus'a hangi temel özelliklerle ulaştığı ve bunun Yunus'u nasıl etkilediği üzerinden Yunus'un düşünce tarihindeki yerini tespit etmekle ilgili bir araştırma amaçlanmıştır. Bunun için Yunus'u etkileyen tasavvufun din bilimleri içindeki büyük itirazını hesaba katarak Tanrı-şeriat, Peygamber-hadis, ahlak-ibadet ve yükümlü insan ile insan-ı kâmil gibi ana kavramlar üzerinden takibi yapılmıştır. Yunus'un ezelî insan telakkisine özel bir yer ayırarak onun düşüncesinin en önemli kısmının burası olduğu tespit edilmiştir.

\section{Anahtar Kelimeler \\ Tasavvuf, Yunus Emre, Ahlak, Ezelî Vatan, Aşk}

\begin{abstract}
This article discusses how Yūnus Emre handled the main ideas of Șūfism and created a new language to express these ideas as well as how he interpreted the idea of the primordial nature of humans.

Academic research on the poetry of Yūnus Emre (d. 720/1320?), which began with linguists and literary historians, has recently expanded with growing interest in the field of Șüfism. However, one of the reasons why the search for "reality" is weakened is because information about the historic figure of Yūnus Emre is entwined with legends. The first story told and written about him has made him one of the most popular legends of Șūfi history, and the dilemma between grain and spiritual power (himmat) has become the most brilliant symbol of the spiritual and temporal world that we live in. Hence, like the ambiguity of his life story, his poetry and works have been indefinite, and his identity becomes undiscernible in an anonymous narrative, most of which contributed by himself. Thus, as Yūnus says "one hundred thousand dervishes are the same, no 'other' steps in." Yūnus
\end{abstract}

* Sorumlu Yazar: Ekrem Demirli (Prof. Dr.), İstanbul Üniversitesi, İlahiyat Fakültesi, Temel İslam Bilimleri Bölümü, İstanbul, Türkiye. E-posta: ekrem.demirli@istanbul.edu.tr ORCID: 0000-0001-9063-846X

Atrf: Demirli, Ekrem. “Yunus'un Tasavvuf Anlayışının Kurucu Unsurları: Ezelî İnsan ve Kadim Tanrı Arasında Aşka Dönüşen İman.” darulfunun ilahiyat 32, 'Yunus Emre' Özel Sayısı (2021): 43-66. https://doi.org/10.26650/di.2021.32.1027987 
has been considered part of the Șūfi community; hence, his authenticity is not questioned. However, he has become a dominant public figure that many poets aspired to become and imitate his works, including signing his name on their works. Studying a thinker or a poet requires exploring their creativity by regarding what they have contributed to the thought, which is the basis for this study. This article determines where Yūnus stands in the history of thought by analyzing his place within the tradition, how Șūfism, which shaped his thinking reached him, and how it affected him. Therefore, to achieve the aforementioned, this article while considering the objection raised by Șūfis toward the religious sciences, analyses concepts such as God-law, Prophet-tradition, morality-worship, and obliged man-perfect man. Simultaneously, it pays special emphasis on Yūnus Emre's idea of primordial man, concluding that it is the most important point of his thinking.

\section{Keywords}

Șūfism, Yūnus Emre, Akhlāq, Eternal Homeland, 'Ishq

\section{Extended Summary}

Local languages played an influential role in the dominant presence of Arabic, one of the most striking aspects of the spread of Sunfism in Islamic societies. Arabic is the language of the Divine Book, Glorious Qur'an, and hadiths of the Prophet, which explains its prevalence in the Muslim world. Therefore, Arabic has always been and will continue to be the most important language of Islam, and, consequently, Quraysh will maintain its privileged position. The language of worship, however, has always been Arabic. Hence, even to date, the Muslim world remains united on this topic. Arabic has produced great literature, both as the language of religious life and religious sciences. During this period, there was figuratively no other language of science or thought except Arabic; further, even if there was any other language, it was not highly influential. When Persian gained importance as the first dominant language of the Muslim world, it created friction when it brought down the authority of Arabic. Later, more languages gained authority, and it helped the Muslim world communicate with their societies. It was primarily the Șufis who expressed religious thought and morality in these local languages, and the expressions full of supplications and prayers used by Șüfis played an important role in infusing the religion to these languages.

Yūnus Emre is one of the most influential figures who helped the Turkish turn into a language in which religious thought was shaped and gained new ways of expression in the Muslim world. His creation of this language was influenced distinctively by thoughts inherited from Șūfi history. First, in his understanding of Șūfism, we can find some critical aspects similar to the criticism of other religious sciences raised by Șūfis. One example is the criticism directed toward other religious sciences by Șūfis on the concept of God. Suufis advocated and pursued a religious life centered on God from early times, and they were expressing their thoughts with a language formed according to this understanding. This understanding was entailed by Tawhid, one of the most significant principles of the religion. However, Șüfis and other religious scholars approached the concept of Tawhid from different perspectives and interpreted it according to their understanding. According 
to the representatives of normative traditions such as Canonists and Theologians, Tawhid is to live in this world by the Divine law, obeying the rules designated by God. Canonists approached Tawhid in terms of Sharia (Divine law), while Theologians were focusing on the authentic faith in terms of divine names. Șüfis objected and argued that Tawhid was the foundation of a strong and dynamic relationship between God and man. Thus, they maintained the idea of building a relationship with God, who was believed to be the reason behind all actions, by transcending causality. They believed that God was the real subject and human beings had to live their lives as objects of the actions of God. This approach led Șüfis to adopt a rambling language that they reached by deconstructing the existing one. Șūfis started using phrases such as "knowing God through God," "speaking through God," or "hearing God," which were unfamiliar to the other Muslim communities. However, they put the concept of love at the center of religious life. Yūnus Emre approached Șüfism considering that its main issue was its way of understanding God. The concept of active God is at the heart of his poems. Thus, God is the reason for every action and deed of humans. Therefore, religious life is a life devoted completely to God. Consequently, this understanding of God helped Yūnus Emre reach the concept of love and handle the relationship between God and man with respect to love. However, love is a concept that emerged from an interpretation of the relationship between God and man in a way that is unacceptable to the Theologians. The idea of love emanates from seeing the relationship with God as never-ending. God is neither far from us nor is He the ultimate unknown. Contrarily, He is closer to man than his jugular vein and is the true subject behind every action. Therefore, while our knowledge about Him is stable, our inability to see Him creates in us a tremendous desire. Once humans experience this desire, they should build a relationship with God. This thought expressed in Turkish by Yūnus Emre maintains that the consequence of love is to take the relationship with a desire and longing on one's heart. On the other hand, his poems are full of concepts and narratives expressing the passiveness of man in this world, such as submission to the power of God or being the addressee of the Divine voice. These concepts and thoughts are well-known throughout the early periods of Șüfism.

Nevertheless, we can also follow the footprints of the early periods of Șüfism on the poems of Yūnus Emre in the way that he prioritized morality before worshiping, one of the fundamental problems encountered by the Șüfis in the period called "Sunni Șüfism," referring to the time after Junayd al-Baghdadi (d. 297/909). The Muslim society had a dilemma because the Canonists and Theologians belonging to the normative side of the religion did not see morality as a fundamental issue and accepted it as the good deeds that should be performed. However, Șūfis focused so much on morality that they treated worship as less important. Therefore, the tension between morality and worship became a serious problem in Șūfism. We witness that Yūnus Emre inherited this problem as it was. Some of his poems have such an emphasis on morality that they can weaken the motives to worship or at least will contradict the expectations of the normative tradition. For example, 
consider this verse from his poem: "If you have broken a heart, your prayer is nothing but in vain." Yūnus Emre emphasizes that the essential principle for humans is morality and by pointing out that there is no limit to this morality, he developed a model of dynamic morality, which stands on the opposite of the uncomplying and unchangeable rules of worship. His poem placed priority on morality over worshiping and with this attitude, Yūnus Emre gets involved in the controversy that started in the early period of Șüfism. Furthermore, another issue that needs to be addressed is prophethood. Șüfis changed the religious understanding of prophethood and turned their attention toward the Prophet rather than his tradition and hadiths. The natural consequence of this understanding is the development of the idea of Haqiqat al-Muhammadiyya i.e. "the Reality of Realities." We cannot find traces of this exact notion in the poems of Yūnus Emre. However, there is a similarity of the notion from another perspective. His idea is based upon the primordial nature of human beings. Thus, this idea of the primordial nature of human beings is the result of Haqiqat al-Muhammadiyya or vice versa. His thought was shaped around this idea. According to Yūnus Emre, humans are eternal, having a primordial reality preceding the creation in the sensible world. Hence, this reality, which is Arsh and Kursi (Throne and Footstool), is immutable before being created, and human's relationship with God originates from this primordial nature. This concept of primordial nature that has been extensively discussed by metaphysicians like Ibn Arabî (d. 1240) finds voice in the poems of Yunus Emre, who sees it as the basis that enables the relationship between God and man.

This concept of primordial nature is a vital factor that unravels almost all the problems of Șūfi morality. Therefore, this concept reviles that this temporal world should be viewed as a bridge to be crossed and not a place to call home. It is a concept that can be associated with asceticism and issues related to it. However, considering the primordial nature, even asceticism, which means renunciation of the temporal world is not enough; thus, asceticism should be disregarded. However, for an ascetic, the afterlife should be abandoned just like the temporal world. Human yearns for God and seeks to see Him; anything beyond that is worthless. Yūnus Emre believes that the fear of hell and hope for heaven, one of the main reasons why humans worship God, should be abandoned as well. He has been criticized severerly because he despises the blessings of heaven and handles the idea of hell in a way that is unacceptable to the normative tradition. In conclusion, the main theme of the poems of Yūnus Emre is God and man whose primordial nature has the potential to reach Him. 


\section{Giriş Yerine: Anonim Anlatıda Birey Kalabilmek}

Bir düşünürün bilim ve düşünce tarihindeki yeri kadar onun gerçekte kim olduğunu tespit etmek güç, güç olmanın ötesinde imkânsıza yakın bir iştir. Bunun nedeni düşünürü gelenek dâhilinde ayrıştıran ana özelliği tespitin her zaman mümkün olmayışıdır. Öyle ki belirli bir gelenek içinde konuşan-yazan birçok yazar ve düşünürün varlığının silindiğine ve anonim anlatımın sözcüsü olmanın ötesine geçemediğine şahit oluruz. Bir gelenek içinde ürün vermek, gelenekteki yerleşik dili ve kavramları kullanmak, geleneğin genel sorunsalının bir parçası olmak, bireyselliği ya tamamen ortadan kaldırır veya dikkatimizi çekmeyecek seviyelere indirir. Düşünürün kullanabileceği hemen her kavram, dile getirdiği her düşünce daha önce belirli bir şekilde dile getirilmiş, her kavram ve her kelimeye temas edilmiş olabilir. Bazen böyle kaygıların modern insanın meselesi olduğu, geleneksel toplumlarda bireyselliği korumanın ciddi bir mesele teşkil etmediği akla gelebilir, gerçekte böyle bir durum söz konusu değildir. Geçmişte veya günümüzde bireyselleşmek, bir yazar olarak özgün olmak, adıyla ve namıyla yer almak arzusu güçlü bir yazarlık saiki olarak bulunmuştur. Hücvîrî'nin (ö. 465/1072 [?]) eserinde "Ben Ali b. Osman derim ki” şeklinde yer verdiği ifadeleri, bunun basit bir örneği olabilir. ${ }^{1}$ Bunun gerekçesini anlatırken kitaplarını "intihale karşı" koruma niyetini beyan eder. Bununla birlikte anonim anlatımlar, kavramlar yazarın kimlik bulmasını zorlaştırır, en azından söylenen düşüncenin başka bir düşünürce dile getirilmiş olması imkân ve ihtimal dâhilindedir. $\mathrm{O}$ zaman bir düşünürü böyle bir bağlam içinde "düşünür” kılan şey nedir sorusu, cevabı çetin bir soru olarak kalacaktır.

Bu meyanda iyi bir örnek Yunus Emre'nin (ö. 720/1320 [?]) şiirleridir.2 Onun şiirinde zikredilen hemen her konunun veya kavramın tasavvuf metinlerinde bulunması mümkün, hatta kaçınılmaz bir durumdur. Böyle iken Yunus'u bir gelenek anlatımında yitirerek -ki kendisi de buna istekli olabilir- onu anonim anlatının bir sözcüsü haline getirmek muhtemeldir. Başka bir anlatımla onu genel dilin kalıpları ve anlatımları arasında yitirerek özgünlüğünü tespit edebilmemiz mümkün olmaz. Hiç kuşkusuz Yunus Emre'nin şiirlerinde karşılaşabileceğimiz ciddi problemlerden birisi budur. Birçok Yunus'un arasından Emre olan Yunus'un kim olduğu sorunundan daha önce, gerçekte Yunus var mıdır, yok mudur sorusunu daha dikkatli bir şekilde sormak gerekir. ${ }^{3}$ Okuduğumuz düşünceler ve ifadeler Yunus'un mudur, yoksa Yunus

1 Bkz. Ali b. Osman el-Hücvîrî, Keşfü'l-mahcûb, nşr. Valentin Aleksiyeviç Jukovski, haz. Kâsım Ensârî (Tahran: Kitâbhâne-i Tahûrî, 1375hş./1996); Ali b. Osman el-Hücvîrî, Hakikat Bilgisi, trc. Süleyman Uludağ (İstanbul: Dergâh Yayınları, 2014).

2 Yunus'un hayat hikâyesi ayrıntılı bir tahlil için bkz. Mustafa Tatc1, "Yunus Emre'nin Hayatı, Sanatı - Şiir Dünyası”, Dîvân-ı İlâhiyât içinde, mlf. Yunus Emre (İstanbul: H Yayınları, 2014), 9-168.

3 Bu konu hakkında bkz. Mustafa Tatcı, “Âşık Yunus ve Başka Yunuslar”, Dîvân-ı İlâhiyât içinde, 629-646. 
daha önce teşekkül etmiş bir dili mi kullanıyor, yoksa anonim bir anlatım Yunus'u mu yönlendiriyor? Burada müşterek bir gelenek derken birçok kanaldan süzülerek gelen bir disiplinin birleştirici yönünden söz ediyoruz. Haddizatında anonim olan bu dil bireyi yönlendiriyor, onu bir çerçeve dâhiline yerleştiriyor. Bu durumda Yunus üzerinde dursak bile onun kavramlarının derinliğini ve istikametini belirleşen şey tasavvuf olacağı için biz de tasavvufa itimat ederek yorum yapacağız. Yunus'un şiirlerindeki tasavvuf telakkisini tespit etmeliyiz ki Yunus'u yönlendiren veya onun katkı sağladığ 1 disiplinin şiirdeki etkilerini fark edebilelim. Bunu tespit ederken tasavvufun mümeyyiz nitelikleri nedir diye düşünmemiz gerekir. Bu meyanda akla gelen birkaç hususun Yunus'un metinlerinde bariz bir şekilde ana mesele haline geldiğini göreceğiz.

\section{Tasavvuf ve Yunus: Geleneksel Anlayışın Reddi veya "Tasavvuf Barışsız Savaştır"}

Tasavvuf, bütün mistik ve gizemci geleneklerde bulabileceğimiz şekilde, reddediş, zihinsel veya toplumsal hayat tarzlarına karşı ciddi bir itiraz şeklinde ortaya çıkmıştı. Günümüzde bazı yazılarda tasavvuf uzlaşma ve hoşgörü zemini olarak telakki edilir, öyle olduğu varsayımından hareketle tasavvuf savunuları yapılır. Uzlaşmacı tutum bilhassa Türkiye'deki akademik tasavvuf yazılarına hakim olmuş, tasavvuf eleştirileri bertaraf edebilmek üzere tasavvufun din bilimlerinin ana fikirleriyle uzlaştı̆̆ iddiasından hareket edilmiş̧ir. Bu bakış açısına sûfîler ile ilgili birtakım tasavvurlar da eklendiğinde durum daha müphem vaziyet kazanır. Bu meyanda sûfîler öteki insanlara karşı sevgi, hoşgörü, karşılaştıkları hadiseleri rıza ile karşılamak gibi daha çok edilgenlik ve teessür gibi niteliklerle nitelenerek tasavvufun eleştirel kısmı ya büsbütün ortadan kaldırılır veya etkisizleştirilir. Yunus Emre ise böyle bir algıdan önemli ölçüde nasibi alarak uzlaşmanın ve hoşgörünün en önemli sembolü haline gelir.

Yunus Emre'nin şiirini doğru bir yere yerleştirebilmek için tasavvufun eleştirel üslubuna ve kavgacılığına hakkını vermemiz gerekir. Haddizatında söz konusu eleştirel tutumun tasavvufun erken evresinde -Cüneyd sonrasında- ortaya çıkan Sünnî tasavvuf anlayışı ile köken açısından benzerlik taşıdığını kabul edebiliriz. Sünnî tasavvuf anlayışı, tasavvufu tedvin sürecine dâhil ederken öteki din bilimleriyle en azından alan ayrışmasını kabul ederek tasavvufun söz konusu alanlarda o bilimlerin otoritesi kabul ettiğini varsayar. ${ }^{4}$ Modernleşme sürecinde ortaya çıkan "zühtsüz riyazet" evresindeki savunmacı dil ise daha toplumcu ve uzlaşmacı bir mahiyet arz ederek birinci evreden de kopar. Yunus'un anlaşılmasının önündeki engellerden

4 Ekrem Demirli, “Zahirî İlimlerin Otoritesi Karşısında Tasavvuf’un Meşruiyet Arayış1,” İstanbul Üniversitesi İlahiyat Fakültesi Dergisi [Darulfunun Illahiyat] 15, (2007): 219-244. 
birisi, kendisini bir dil kurucusu haline getirmekle neticelenen tasavvufun çatışmacı ve eleştirel üslubunu unutmaktır. Yunus yeni bir dil kurabildiyse bunun en önemli nedeni bu çatışma ve uzlaşmaz zemindir.

O zaman Yunus'un şiirini anlayabilmek için tasavvufun eleştirel dilini ve üslubunu hatırlamak şarttır. Gerçekte tasavvuf din bilimlerini teşkil eden hemen bütün disiplinlerle değişik veçhelerden çatışmalar dâhilinde ilerlemiş, o bilimlerin din telakkisini reddederek "hakikat" diye isimlendirdiği bir şeye varmak üzere meşakkatli bir yol ve yöntemi takip etmeyi önermiştir. Bu yöntem zaman içinde birtakım değişiklikler arz etse bile, özünde değişmemiştir: bu yol ahlakla başkalaşmak ve hakikate uygun bir hale gelebilmek için değişim yoludur. Yunus Emre ve benzeri sûfîlerin ifadesiyle "hamlıktan pişmeye doğru" bir tahavvül, yani halden hale girmektir. Tasavvuf ne fikıh ne hadis ne kelam ve ne de o bilimlerin metin (Kur'ân-1 Kerim ve Sünnet) yorumculuğu ile barışık olabilmişti. Her şeyden önce tasavvuf öteki din bilimlerini hem yöntem hem amaçları bakımından "yetersiz" görerek hakikati başka bir yerde ve yöntemle aramanın gerekliliğini savunmuştu. Buna, içinde metafiziğin de bulunduğu felsefi bilimler doğal bir şekilde dâhildir. Daha sonra Gazzâlî’de karşıllaştı̆̆ımız kelam başta olmak üzere din bilimlerinin yetersizliği sorunu tasavvufun doğuş ve gelişim nedenlerinin başında gelir. "Din bilimleri dinin amaçlarını -ki bu amaçların en önemlisi insanın yetkinleşmesidirgerçekleştirmede yetersizdir" iddiası tasavvufun bütün dönemlerinde süregelen en güçlü ve önemli iddialarından birisidir. ${ }^{5} \mathrm{Bu}$ itibarla tasavvuf "hakikat" tabirini kullanmaya başladıktan sonra din bilimlerinin içeriğinde bir zayıflama ortaya çıkacağı gibi aynı zamanda öteki bilimler de meşruiyetini yitirmeye başlarlar. Tasavvufta anlatılan hiçbir konu veya ele alınan hiçbir mesele esas itibariyle din bilimleriyle barışa, uzlaşmaya ve onların kavramlarına geri dönmeye müsait değildi.

Tasavvufun din bilimlerine yönelik üç temel eleştiri konusu Yunus'un şiirlerine hakim düşünceleri anlamaya katkı sağlayacaktır. Bunlardan birisini daha ayrıntılı ele alacağız, lakin öncesinde iki hususa dikkat çekmek gerekir: Bir dinde ana konu Tanrı'dır, bunda tereddüt yoktur. Tanrı'nın varlığı, onun insanla ve âlemle ilişkileri tevhidin konularını teşkil ederken dindarlık Tanrı ile yaşamak adını alır. Lakin zamanla şeriat-yasa öne çıkarak “Tanrı" hakkındaki düşünceler “Tanrı'nın yasası ve kuralları" hakkındaki düşüncelere yerini bırakır ve dindarlıkta temelden bir değişim yaşanır. Böylece Tanrı'yla ilişkimiz ahirete tehir edilerek yeryüzündeki ilişkinin zemini tezyif edilir. Tasavvuf önce bu değişime -gerilemeye- itiraz ederek din bilimlerinin soğuk ve "ayık" haline karşı coşkulu dinî hayatı savunmuştur. Sûfîler "vecd" dediklerinde gerçekte buradaki hakikati bulmaktan söz ettikleri gibi

5 Ebû Hâmid el-Gazzâlî, el-Münkızz mine'ḍ-ḍalâl, nşr. Cemîl Salîbâ-Kâmil Ayyâd (Dımaşk: Matbû‘âtu Mektebetü'n-neşri'l-'Arabî,1358/1939). 
hakikat de şöyle veya böyle Tanrı demekti. Artık tasavvuf Tanrı'yla yaşamak ve Tanrı'yla konuşmak, söyleşmek, Tanrı'yı görmek gibi birçok kavramı öne çıkararak dinî hayatın soğukkanlı kalıplarından daha coşkulu bir hali sûfîlerin gündemine taşımış oldu. ${ }^{6}$ Bunu “Tanrı'yı dünyaya çağırmak” veya O'nu dünyada bulmak diye ifade edebiliriz. Yunus'un şiirleri Tanrı ile yaşamak, Tanrı'yı burada hatırlamak, Tanrı'yı burada görmek üzerine kurulu şiirlerdir ve bu nedenle de bir itiraz şiiridir.

Yunus Emre'de gözleyebileceğimiz ikinci temel husus ise tasavvufun peygamber telakkisiyle ilgili bahislerdir. Nübüvvet dinî hayatın meşruiyet sebebidir, bunda tereddüt yoktur. Bir din peygamber tarafından getirildiği için din olmuş, ahlak ve yasalar o sayede dinî hüküm olmuştur. Bilhassa İslam, öteki dinlerle karşılaştırılmayacak ölçüde nübüvvet merkezli bir dindir. Tasavvufun öteki bilimlere yönelik eleştirilerinden birisi de nübüvvet ekseninde ortaya çıkan eleştirilerdir. Öncelikle hadisçiler din bilimleri arasında hemen her disiplin ile kavga içinde şekillenmiş, sûfîleri bidat ehli olarak görmüşlerdir. Tasavvufun tedvin öncesinde sûfîlerin nasıl bir nübüvvet telakkisine sahip olduklarını bilmiyoruz. Zamanla sûfîler "Hakikat-i Muhammediye" fikrini geliştirmiş, bunun ilk nüveleri ise Sünnî tasavvuf evresinde ortaya çıkmaya başlamıştır. ${ }^{7}$ Hakikat-i Muhammediyye, herhangi bir şekilde Ehl-i hadîs'in ve normatif geleneğin kabul edemeyeceği birtakım düşünceler içerir. Bunun temel nedeni bu düşüncenin aynı zamanda insanla ilgili birtakım büyük iddiaları beraberinde getiriyor olmasıdır. Başka bir anlatımla Hakikat-i Muhammediye öncelikle Hz. Peygamber hakkında, dolaylı olarak da insan hakkındaki kapsamlı bir düşüncedir. ${ }^{8} \mathrm{Bu}$ düşünce her iki aşamasıyla birlikte din bilimlerinin telakkilerine aykırı idi. Bu itibarla tasavvuf, şeriata ve yasaya mukabil Tanrı'nın zatı üzerinde odaklanmış iken sünnet ve hadise karşı da Peygamber'in şahsiyeti ve ardından da zaman üstü hakikati üzerine odaklanarak büyük bir değişim ortaya koydu. Yunus’ta bu düşüncenin ikinci kısmının izlerini bulabiliriz, buna mukabil nübüvvet hakkındaki görüşlerde Yunus Emre Ehl-i hadîs’in de kabullenebileceği "duygu" merkezli birtakım şiirler dile getirmiştir. Söz konusu şiirler kendisine ait ise bu şiirleri daha çok "peygamberi özlemek" ana fikrinde toplamak mümkündür.

6 Vecd kavramı hakkında bkz. Ebü’l-Kāsım Abdülkerîm b. Hevâzin el-Kuşeyrî, er-Risâletü'lKuşeyriyye, nşr. Enes Muhammed Adnân eş-Şerfâvî (Cidde: Dâru'l-Minhâc, 1438/2017), 245250.

7 Bazı örnekler için bkz. Sehl b. Abdullah et-Tüsterî, Tefsîrü'l-Kur 'âni'l- 'ażîm, nşr. Muhammed Bâsil Uyûn es-Sûd (Beyrut: Dâru'l-Kütübi'l-İlmiyye, 1428/2007), 27-28; Hallâc-1 Mansûr, Kitâbü 'tTavâsîn, nşr. Louis Massignon (Paris: Geuthner, 1913), 191-194.

8 Kavramın bu yönü hakkında bkz. Ekrem Demirli, İslam Metafiziğinde Tanrl ve İnsan (İstanbul: Kabalc1 Yayınları, 2009), 237-305. 
Bununla birlikte peygamber telakkisinin "sözden" ve uygulamadan şahsa ve hakikate doğru intikal etmesiyle birlikte, çok önemli bir konu daha dinî hayatın merkezine yerleşti: ahlak! Tasavvufun ahlak telakkisi, Tanrı tasavvuru ile nübüvvet ve insan telakkisinin bir sonucu şeklinde öne çıkarak daha önce dinî hayatta amellerden birisi iken bu kez dinî hayatın amacına dönüşmüştür. Yunus Emre'de görebileceğimiz en önemli değişimlerden birisi ahlakın "amaç" şeklinde telakki edildiği bu dindarlık tarzı olacaktır. Vakıa, Yunus Emre için ahlak, amellerden birisi veya salih amel değildir; o amellerin bizzat gayesidir. Öyle ki ahlak yok ise ameller boş ve anlamsızdır. Bu noktada Yunus'un şiirleri insan sevgisi, cömertlik -ölçüsünü bilemiyoruz-, affetmek, gönül yapmak gibi ahlakın ana unsurları saydığı eylemlerle doludur. Haddizatında ahlak ve ameller arasında ortaya çıkan karşıtlık tasavvufun yol açtığı meselelerden birisidir. Bu meyanda ahlak, hiç kuşkusuz, geleneksel dinî hayatta da yer alıyor, fikıh kadar hadis ilmi de ahlaka atıflar yapıyordu. Fakat onların anladığı haliyle ahlak ile sûfîlerin sözünü ettiği "ucu açık" ahlak arasında sadece isim benzerliği olabilir. Sûfîler dinî hayatın odak noktasını, sınırlarını ve ölçülerini hiçbir zaman tam olarak bilemeyeceğimiz ahlaka taşıyarak "ameller" alanını ya tezyif etmişler ya da büsbütün boşaltarak ibâhî eğilimlerin önünü açmışlardı. "Bir kez gönül yıktın ise bu kıldığın namaz değil”’ mısra1 -Yunus'a aidiyetinden kuşku duymadığımız takdirde- tasavvufun nübüvvet telakkisinin bir sonucu olmak üzere, ameller ile ahlak ilişkisindeki yeni yaklaşımını gösteren en nefis örneklerden birisidir.

Burada son olarak bir hususa daha dikkat çekerek Yunus Emre'nin düşüncesindeki yeni bir unsura eğilmiş olacağız: Tasavvufun bütün bu itirazlarındaki ana fikri, insanı temel bir konu olarak ele almış olmasıdır. Tasavvuf bir din bilimi olarak kendisini marifetü'n-nefs, yani insanı tanımak diye ifade eden bir disiplindir. Öte yandan gayesi bakımından ise marifetullah, yani Allah'ı tanımak diye kendini adlandırır. Öyle veya böyle, tasavvuf Tanrı ve Allah’1 tanımak üzerine kuruludur. Bütün bu değişimlerin nedeni budur. Bu meyanda normatif geleneğin ne yaptığını bilhassa insanla ilgili yaklaşımını hatırlamadan tasavvufun getirdiği değişimin ölçülerini kestiremeyiz. Gerçekte en büyük çatışma bu noktada, yani insan telakkisinde ortaya çıkmış idi. Normatif geleneğin insan telakkisi "yükümlü insan" anlayış1 üzerine kuruludur. İnsan kişisel veya toplumsal hayatında birtakım sorumluluklarla yükümlüdür, bunlar dince belirlenmiştir ve dünya hayatına bir düzen getirmiş olsalar bile esas faydaları ukbâda ortaya çıkacaktır. Bu yönüyle dinî hayat öteki dünyaya odaklanmış, Tanrı'nın ahiret hayatındaki ödül ve cezasını dinî hayatın

9 Yunus Emre, Dîvân-ı İlâhiyât, haz. Mustafa Tatc1, 3. bs. (İstanbul: H Yayınları, 2014), 362. Yunus'un burada ve bundan sonraki şiirlerini zikrederken, Tatcı'nın neşrini dikkate almakla birlikte günümüz Türkçesine uyarlayarak aktarmayı tercih edeceğim. 
saiki haline getirmişti. Dünya hayatında herhangi bir şey beklemek veya insanın bu yükümlülüklerle ulaşabileceği birtakım lütuflardan söz etmenin bir anlamı yoktur. İnsan gerçekte ahiret yurdunda saadete ve selamete erecektir. Tasavvuf tam olarak bunu değiştirdi. "İnsan yükümlü varlıktır” ilkesi korunsa bile -özellikle Sünnî tasavvufta- insanın varlıktaki yeri, Tanrı'nın onunla ilgili amaçları, insanın değeri, hepsinden önemlisi de ahlaki hayatın sonucunda varabileceği makam ve mertebeler, tasavvufun esas konularını teşkil etmişti. Bu yönüyle Yunus Emre'nin tasavvufu Tanrı'yı bilmeyi amaç edinmiş insanı tanıma hedefi üzerine kuruludur. Şimdi bu hususlara daha ayrıntılı bir şekilde bakabiliriz. Bu meyanda dikkat çekmemiz gereken ilk konu Tanrı telakkisindeki değişime bağlı olarak dilde ortaya çıkan değişimdir. Daha doğrusu tasavvufun bu alanda yaptığı değişimi dildeki değişim üzerinden tespite çalışacağız.

\section{Yunus'un Tasavvufu: Tanrı’nın Özne Olduğu Bir Dili Kurmak}

Arapçanın Müslüman toplumun genel ve hakim dili oluşu ilahi kelamın dilinin olmasıyla yakından ilgili bir durumdu. Müslümanlar ilk dönemlerden itibaren dil hakkında güçlü bir teori sahibi olmasa bile, bir sezgiye sahiptiler ve bu sezgi Arapçanın bir dil olarak içerdiği düşünme biçimi hakkında belirleyici bir perspektife yol açmıştı. İlahi kelamın dilinin Arapça olması aynı zamanda Arapçanın bir düşünme kalıbı kabul edilmesini iktiza ediyordu. Bu bakımdan başta Selefî yorum ile onu bir ölçüde takip eden usul bilginleri olmak üzere birçok yorumcu ilahi kelamın anlaşılmasının Arapça sınırları dâhilinde olabileceğini düşünmüşlerdi. Şia teorisinin güçlenmesiyle birlikte "dil" eksenli anlayışın yerine "imam" anlayışı getirilmek istense bile, hakim düşünce metnin dil sınırlarıyla anlaşılmasını savunan yaklaşım olarak kalmıştır. Kelam, fikıh ve selefî düşüncedeki "Sünnîlik" bu şekilde teşekkül etmişti. Hz. Ebû Bekir'in de rivayet ettiği kabul edilen "Halifeler Kureyş’tendir" sözü, ${ }^{10}$ Müslüman toplumun sadece siyasal ufkunu değil, aynı zamanda entelektüel ufkunu da çiziyordu. Bundan sonra Kureyş’in idrak seviyesi dinî hayatın sınırlarını çizen en önemli faktör olmuştur. Fakat tasavvuf bu telakkiyi değiştirerek dil merkezli anlayıştan Tanrı'nın doğrudan konuştuğu bir telakkiye doğru intikal etmek istedi. Bu yaklaşım özünde çok önemli değişim iktiza ediyordu, bunda tereddüt yoktur. Çünkü Tanrı'nın doğrudan konuşması demek, dillerin aracılığı olmaksızın, her insana hitap etmesi demek iken aynı zamanda her bir kişinin de Tanrı ile konuşabilmesi anlamını içeriyordu. Tasavvufun İslam toplumunda yaptığı en önemli işlerden birisi Tanrı'nın gerçek bir özne olarak dile tecelli etmesiyle birlikte, doğrudan konuşmanın imkân dâhiline girmiş olmasıdır. Bunun nasıl yapıldığını görelim:

10 Ebü'l-Abbâs Ahmed b. Yahyâ el-Belâzürî, Ensâbü'l-Eşrâf, thk. Riyâz ez-Ziriklî-Süheyl Zekkâr (Beyrut: Dâru'l-Fikr, 1417/1996), 1/582, 584. 
Tasavvuf yükümlülük üzerine kurulu dinî anlayışı esasta reddedemez, lakin burada fikıh merkezli dinî anlayış insanın ulaşabileceği hemen bütün neticeleri öte dünyaya taşıyarak dünyayı kutsallıktan boşaltıyordu. En azından tasavvufun meseleye yaklaşımı buydu. Sûfîler ise "Allah rizası" tabiriyle cennetteki nimetler ve riza yerine dünyada rıza kavramına vardılar. Yunus'un şiirlerinde bu anlayışı fark ederiz. Her şeyden önce Yunus, Tanrı' dan bir muhatap olarak söz ederek şiirini bir niyaza döndürür. Bunun nedeni dinamik Tanrı telakkisidir, bunda tereddüt yoktur. Bu anlayış içinde dildeki ilk büyük değişimi fark ederiz. Yunus'un Tanrı telakkisinin yol açtığı ilk şey, dilde öznenin yer değiştirmesi olacaktır. Hiç kuşkusuz bu durum, daha önce tasavvuf tarihinde yaşanan en önemli hadiselerden birisiydi. Bâyezîd-i Bistâmî (ö. 261/875 [?]) "anane" şeklinde aktarılan bilgiye mukabil "doğrudan" bilgiyi savunurken tam olarak bunu ifade etmiş, Allah'1 "bilgiyi öğreten" olarak kabul etmiş, "Biz bilgimizi ölümsüz Hayy'dan alıyoruz" demişti. ${ }^{11}$ Bundan sonra sûfîler için başta bilgi olmak üzere hemen her konuda Tanrı hakiki özne olarak ortaya çıkmış, yeni dil anlayışı Tanrı'nın özneliği merkezinde ihdas edilmişti. Bu yaklaşımın Yunus Emre'de de olduğu gibi sürdüğünü fark ediyoruz. Yunus Emre bunu insanın sahip olduğu güç ve kuvveti reddederek güç ve kuvvetin Tanrı' da bulunuşuyla açıklar: "Sensiz yola girer isem çarem yok adım atmaya" derken tam olarak bunu fark ederiz. ${ }^{12}$ Haddizatında bu yaklaşım dinî düşüncenin istilzam ettiği güç ve kudreti Tanrı'da toplamanın bir neticesi olmakla birlikte Yunus -ve öncesinde sûfîler- bunu hayatın bütün alanlarına taşırlar. Şiirin devamında "Gövdemde kuvvetim sensin başım alıp götürmeye" derken de aynı şeyi beyan eder. ${ }^{13} \mathrm{Bu}$ şekilde "Tanrı ile konuşma" tarzında ortaya çıkan şiir, muhatabı değiştirerek, dildeki ilk büyük değişikliği yapar. Haddizatında bu değişim tasavvufun Müslüman düşünceye getirdiği en önemli yenilik idi.

Tanrı ile böyle bir konuşma biçimi Hakk'1 duymak, Hakk'1 görmek şeklinde tasavvuf düşüncesinde başından beri gözüken başka bir anlatım biçiminin devamıydı. Bu noktada Yunus'un Tanrı ile ilişkiyi -iman üzerinden değil- aşk üzerinden kurmakla söz konusu değişimin zeminini inşa ettiğini görebiliriz. Yunus'un şiirlerinde aşk, imanın en kuvvetli halidir. Yunus aşk üzerinden kurduğu Tanrı-insan ilişkisinde Tanrı'yı maşuk olarak görünce, insanın payına düşen şey, gurbet, yalnızlık, iştiyak gibi haller olacaktır. Bunun sonucu ise insanın aciz, güçsüz, zayıf kalmasıdır. Tanrı'yı gücün kaynağı olarak görmek ve her işi O'na bırakmak, tevekkül anlayışını ortaya çıkartmışken bunun ahlaki hayattaki karşıllı̆ı ise züht, rıza ve teslimiyettir. Yunus'un teslimiyet ve rıza ilgili şiirlerini bu eksende yorumlamak gerekir.

11 Muhyiddîn İbnü'l-Arabî, Fütûhât-ı Mekkiyye, trc. Ekrem Demirli (İstanbul: Litera Yayıncılık, 2006-2012), 1/73.

12 Yunus Emre, Dîvân-ı İlâhiyât, 247.

13 Yunus Emre, Dîvân-ı İlâhiyât, 247. 
Burada daha özel bir konuya dikkat çekmek gerekir: Tanrı maşuk ise insanın O'ndan başka bir şeyi sevmesi veya onu arzulaması samimiyet ile bağdaşmaz. Fakat burada dikkatimizi çeken husus âşığın maşuka gitme imkânının bulunmayışıdır; âşı̆̆ kendisine çeken bizzat Maşuk'tur. Bu nedenle tasavvufun erken evresinden itibaren yola girenin ismi mürit iken gerçekte murad, yani irade edilen veya meczup-müncezib gibi Allah'a çekilen kimse olarak kabul edilmiştir. ${ }^{14}$ Yunus bunu meşhur bir şiirinde "Züht ile çok denedik hiç müyesser olmadı" diye anlatır. ${ }^{15}$ Burada sormamı gereken soru şudur: Züht ile olmayan nedir ve bunu mürit ne zaman anlar? Züht belirli bir hesap kitap dâhilinde ukbâ hayatını dünyaya tercih etmek demektir. Bu itibarla züht özünde bir ticaret anlayışı barındırır. Zahitler muhakkik sûfîlerce "ahiret tüccarları" olarak kabul edilirken meselenin zühdün de aşılması olduğunu fark ediyoruz. Yunus böyle bir eylemi aşk ilişkisine uygun görmez; olması gereken şey insanın içinde cennet nimetlerinin de bulunduğu her şeyi reddederek Tanrı'ya odaklanmasıdır. "Uçmak dahi tuzak imiş mümin canların tutmaya" diye betimlediği bu yolculuk, ${ }^{16}$ Yunus'un aşk anlayışının neticesidir. Fakat bunu ancak yolu cennetten geçen, dinî hayat içinde cennetin ötesinde bir anlam bulan birisi söyleyebilir. O anlam, hiç kuşkusuz, Tanrı'nın rızası ve O'nu görmek arzusudur. Öyleyse onun Tanrı anlayışının en önemli yönlerinden birisi, cennet ile cehennem korkusu üzerine teessüs eden dindarlığın yeni bir şekilde yorumlanmasıyla Tanrı'ya “Tanrı için ibadet” veya Tanrı'yı tanımanın dinî hayatın odağına yerleşmesi fikrini savunmasıdır.

Bunun ilk unsurlarını Râbia el-Adeviyye'de (ö. 185/801 [?]) görmekteyiz. Onun ihlas anlayışı daha sonra tasavvuf tarihinde ciddi etki ortaya çıkarmış, birçok sûfî tevhit ile ihlas arasında irtibat kurarken onun gibi düşünmüş, Tanrı'ya ancak O'nun için ibadet etmekle ihlasın gerçekleşeceği fikri tasavvuf metinlerinde sıkça zikredilmiştir. ${ }^{17}$ Haddizatında züht başta olmak üzere tasavvuf tarihinde riyazet için ortaya çıkan bütün yöntemler, insanı ihlasa ulaştırmayı hedefleyen ve bireysel arzulardan uzaklaşmaya yardım edecek unsurlardı. Yunus bunun birçok noktasına dikkatimizi çeken şiirler söyleyerek meselenin cennet ve cehennem olmadığını beyan eder ve zühdü normatif geleneğin anlayışından da büsbütün kopartır. İşin bu kısmı, yani zühdün uhrevi hayatı dünyaya tercih demek olması Ehl-i hadîs ve bazı fakihlerdeki dindarlık anlayışının bir neticesiydi. Sûfîlerin görüşleri böyle bir

14 Ebû Bekir Muhammed b. İbrâhim el-Kelâbâzî, et-Ta 'arrufli-mežhebi ehli 't-tașavvuf, nşr. Ahmed Şemseddin (Beyrut: Dâru'l-Kütübi'l-İlmiyye, 1413/1993), 158-159.

15 Yunus Emre, Dîvân-ı İlâhiyât, 346.

16 Yunus Emre, Dîvân-ı Illâhiyât, 247.

17 Râbia ve görüşleri için bkz. Ferîdüddin Attâr, Evliya Tezkireleri, haz. Süleyman Uludağ (İstanbul: Kabalc1 Yayınları, 2007), 98-112. 
zühdü aşarak dünyayı ve ukbâyı Tanrı için bırakmak anlayışına varmıştı. Yunus'taki züht tam olarak böyledir. Ona göre dindarlık Tanrı aşkı ve O'nu tanımak üzere kuruludur. Bu meyanda Yunus sadece ukbâyı dünyaya yeğlemeyi aşmakla yetinmez, dinî metinlerde cennet ve cehennem ile ilgili geçen ifadeleri de başka bir yoruma tabi tutarak "dili aşan" yorumculuğun en yetkin örneklerini verir. Gerçekte işin bu kısmı üzerinde herhangi bir çalışma yapılmış değildir, fakat yine de bir hususa işaret etmekle yetineceğiz.

Bunların en önemlisi cehennem ve korku ile ilgili ayetlerin yeni bir şekilde okunması meselesidir. Yunus'un daha çok meşhur olan sözleri cennet ile ilgilidir, bu konuda da fetvalara konu olan şiirler söylediğini biliyoruz. ${ }^{18}$ Bu meyanda cennet nimetleri ve cehennem azabıyla ilgili ayetlerin sembolik yorumlanmasından söz etmiyoruz; onları zaten Müslüman filozoflar, hatta onların da etkisiyle pek çok âlim yapmış, cennet nimetlerinin gerçekte birtakım semboller olduğunu beyan etmişlerdi. Fakat Yunus'ta ortaya çıkan şey, böyle bir yorumlama değildir; Yunus cennet ve cehennemi sembolik bir dil sorunu olarak kabul ederek onları yorumlamak, sembollerini çözerek hakikatlere varmak istemez. İster sembol olsun ister olmasın, cennet nimetleri kadar cehennem azabı da Yunus için gerçek bir dinî saik olarak kabul edilemez. Bu itibarla cennet nimetlerinin haddizatında tevili mümkündü; Yunus'ta bunları da görebiliyoruz. Çünkü bütün cennet nimetleri Tanrı'nın rızası ve O'nun yakınlığı ile izah edilebilir. Lakin cehennem hakkındaki yorumlar, metnin başka bir gözle yorumlanması anlamına gelerek dinî nassı Arapça merkezli yorumlama yöntemini tamamen ters yüz etmektedir. Bundan sonra -ki bunun öncesinde Râbia el-Adeviyye'den itibaren bu düşüncelere aşinayız-Arapça merkezli bir din bilimleri usulünün en azından sûfîlerce bir anlamı olmayacak, en yüksek örneğini İbnü'lArabî’de (ö. 638/1240) görebileceğimiz üzere metnin başka bir paradigma içerisinde okunmasının imkânlarını keşfedeceğiz. Meselenin bu kısmı Arapça içerisinde kalarak da yapabileceğimiz bir değişimdir; burada dil çerçeve olmaktan çıkarak yeni metinde saklı hakikat ile başka bir yolla -Tanrı'yı düşünerek- irtibat kurmak zorundayız. Dildeki bu değişimin ikinci merhalesi ise Arapçaya karşı Türkçenin aynı zeminde ortaya çıkmış olmasıdır. Bir dil ana çerçeve olmaktan çıkıp hikmeti anlatan bir yola dönüşünce, onun yerine başka bir dil koymak her zaman imkân dâhilindedir. Demek ki burada esas olan şey, Arapça hakimiyetinin tezyif edilmesiyle ortaya çıkan durumdur. Yunus "Sırat kıldan ince kılıçtan keskincedir"19 dediğinde ve "Varıp o gölgelikte biraz yatasım gelir" dediğinde, ${ }^{20}$ biz artık naslarda zikredileni

18 Mehmet Ertuğrul Düzdağ, Şeyhülislâm Ebüssuûd Efendi Fetvaları Işığında 16. Asır Türk Hayatı (İstanbul: Enderun Kitabevi, 1983), 85-87.

19 Yunus Emre, Dîvân-ı İlâhiyât, 342, 465

20 Yunus Emre, Dîvân-ı İlâhiyât, 257. 
ifadelerin literal yorumunun hiçbir şekilde kabul edemeyeceği bir anlam dairesine taşınmış olduk. Dinî hayatın en önemli saiki olabilecek cehennem korkusunun bu şekilde ilga edilmesi sûfîlerin büyük kısmınca bile şathiye sayılabilir; gerçekte burada şathiye diye bir durum söz konusu değildir. Yunus, Tanrı-insan ilişkisini aşk ilişkisi üzerinden tesis ettikten sonra zorunlu olarak bu yoruma varmaktadır. Bunun örnekleri çoğaltılabilir. Cennet hakkında söyledikleri ise bunun daha azı olmakla birlikte, aynı düşünce dairesinde değerlendirilebilecek birtakım yorumlardır. Her bir yorum metnin Arapça sınırlarının dışına çıkarak okunmasıyla varılan yorumlardır ve her birisi "usul" ilminin zeminini tezyif edecek yaklaşımlardır.

\section{Yunus'ta İbadet ve Ahlak Çelişkisi: Ahlaka İbadetin Maksadı Olarak Bakmak}

Yunus'un şiirlerinde kapsamlı bir Hakikat-i Muhammediye teorisi bulmak güçtür, bu nedenle de $a$ 'yân-ı sâbite hakkında ne düşündüğ̈̈nden emin olamıyoruz. $\mathrm{Bu}$ yönüyle vahdet-i vücûd, iki önermeden birisi olmak üzere $a$ yân- - sâbite anlayışı üzerine şekillenmiştir. ${ }^{21}$ Öte yandan peygamberin hakikati aslında insanın hakikatini de içeren metafizik bir meseledir. Bu konuda bir hadis, tasavvuf metinlerinde aktarılır. Hadiste "Ben peygamber idim, Âdem toprak ve su arasındayken" buyrulmuştur. ${ }^{22}$ Sûfîlerden birisi "Ben veli idim, Âdem toprak ve su arasındayken" dediğinde Hakikat-i Muhammediye ile insanın hakikati arasındaki irtibat tesis edilmiş oldu. Buradan insanın velayeti ve ezelîliği düşüncesine ulaşırız. Yunus'un insanın hakikati üzerindeki görüşleri hakikat-i insaniye fikrinin bir örneği sayılabilir. ${ }^{23} \mathrm{Bu}$ konu üzerinde daha sonra durabiliriz, fakat burada esas dikkatimizi çeken husus ahlak üzerindeki vurgu ile sünnet arasındaki çelişkidir. Daha doğrusu geleneksel hale gelen sünnet ile ahlak hakkındaki farkl11ık Yunus'un görüşlerini anlamamız bakımından hayati öneme sahiptir.

Her şeyden önce Yunus'un ahlakı daha önceki sûfîlerde olduğu üzere normal Müslümanlar için abartılı gelebilecek örneklere dayalıdır. Bu ahlak anlayışı hem

21 Vahdet-i vücûd düşüncesinin, iki temel önermesinden, yani "Mutlak varlık Hak'tı"” ve "A 'yân-1 sâbite ezelîdir" ilkelerinden hareketle bir izahı için bkz. Ekrem Demirli, "Varlık Olmak Bakımından Varlık İfadesinin Sûfîlerce Yeniden Yorumlanması ve Bu Yorumun Metafizik Sonuçları,” İslâm Araştırmaları Dergisi 18 (2007): 27-48.

22 Bu konuda bir örnek olarak bkz. Aziz Mahmûd Hüdâyî, Âlemin Yaratılışı ve Hazreti Muhammed'in Zuhuru, trc. Kerim Kara-Mustafa Özdemir (İstanbul: İnsan Yayınlar1, 1997), 52. Rivayetin hadis eserlerindeki örnekleri için bkz. Ebû Îsâ Muhammed b. Îsâ et-Tirmizî, el-Câmi ' ̈̈̉'l-kebîr, thk. Beşşar Avvâd Ma rûf (Beyrut: Dâru'l-Garbi'l-İslâmî, 1996), "Menâkıb”, 1 (Hadis No. 3609); Ebû Abdullah Ahmed b. Muhammed eş-Şeybânî Ahmed b. Hanbel, el-Müsned, thk. Sidkî Muhammed Cemil Attâr (Beyrut: Dâru'l-Fikr, 1991), 5/59.

23 Bu kavram hakkında bkz. Demirli, İslam Metafiziğinde Tanrı ve Insan, 31, 244, 275. 
amaçları hem uygulamaları hem de bizi götürebileceği sonuçlar bakımından, din bilimlerinin ahlak anlayışından büsbütün farklıdır. Öyle ki ikisi arasındaki irtibatı sadece kelimeler düzeyinden kurulmuş kabul edebiliriz. Başta Tanrı'nın "maşuk" diye ifade edilmesi olmak üzere, hemen her kavram özünde değişiklik arz ederek yapısal bir farklılık ortaya çıkar. Bu meyanda Yunus'un "şeriat gemisi" ${ }^{24}$ diye ifade ettiği şey gerçekte ortalama dinî yükümlülüklerden oluşan kurallar manzumesidir. Bunlar namaz, hac, oruç, zekât gibi dinî emirler ile yine bu eksende teşekkül eden ibadetlerdir. Bunların yanı sıra hadislerde birçok ahlaki ilkeden söz edilse bile, fikıh etkisinde bu hadisler belirli kurallara tahsis edilerek daraltılmış, hepsinden önemlisi böyle konular dinî hayatın esası olarak değil, müstehap ve mendub gibi ikincil alanı ile ilgili görülmüştü. Bu itibarla dinî gelenek içinde ahlak ile ibadetleri ayrıştırabilecek bir sistematik düşüncenin izi yoktu.

Haddizatında genel dindarlık içinde ahlaki ilkelerin ikincil hale gelmesi fikhın zaruri yaklaşımlarından kaynaklanıyordu. Fıkıh olgusal bir yaklaşımla insanın yükümlülügünü zahiri ibadetlerle sınırlı görmüş, öteki ahlaki bahisleri ise ikincil addetmişti. Tasavvuf erken dönemden itibaren ahlakı birinci ve temel mesele haline getirmekle din bilimlerinin telakkisine mukabil büyük eleştirisini dile getirmiş oldu. Bu meyanda ahlak herhangi bir şey ile karşılaştırılamayacak olan ve dinin gayesini teşkil eden meseledir. Şiirlerinde ahlakın "amaç" şeklinde ortaya çıkışının Yunus'taki etkilerini derin bir şekilde fark edeceğiz.

Ahlak dindarlıkta temel mesele haline gelince, Sünnî tasavvuf eserlerinde gördüğümüz üzere, öteki bütün konular ikincil, yer yer önemsiz hale gelmiş oldu. Öte yandan üzerinde durmamı gereken bir konu abartılı tasavvufi hayat örneklerinde gördüğümüz üzere, bu ahlaki bahislerdeki abartılardır. Sûfîler herhangi bir ahlak ile sınırlı kalmayı kabul etmiyorlardı. Mesela onlar için affetmek yeterli değildi, affetmekten vazgeçmek gerekiyordu; onlar için tövbe yeterli değildi onu da unutmak lazımdı. Merhamet ve benzeri hususlarda sınırsız bir ahlaki ölçüden söz edildiğini görmekteyiz. Bu itibarla terk, ahlaki hayatın doğruluk ölçütü haline gelerek "ahlaklanmanın ahlakı" olarak kabul edildi. ${ }^{25}$

Yunus "Bir kez gönül yıktın ise bu kıldığın namaz değil” dediğinde, ${ }^{26}$ ahlak anlayışının ana meselesini bize göstermiş oldu. Ahlakı böyle bir seviyeye taşıyan şey hiç kuşkusuz aşk olmalıdır. Tanrı ile insan arasındaki ilişki aşk ise o zaman ahlak bu ilişkide aşkın hallerinden ibaret olacaktır. Bu durumda ahlakın formu ve

24 "Hakikat bir denizdir şeriattır gemisi”; bkz. Yunus Emre, Dîvân-ı İlâhiyât, 273.

25 Tasavvufî haller ve makamların "terk" unsuruyla beraber ayrıntılı bir tahlili için Fütûhât'ın ilgili bölümlerine bakılabilir. Bkz. İbnü’l-Arabî, Fütûhât-ı Mekkiyye, 7 ve 8. ciltler.

26 Yunus Emre, Dîvân-ı İlâhiyât, 362. 
tanımı da tamamen değişecektir. Yunus Emre ahlaklanmayı dinin amacı sayarak ibadetlerin bizi yüksek ahlaka taşıması gerektiğini söylerken din bilimlerinin yaklaşımlarını ters yüz etmektedir; burada da dilde büyük bir değişim yaşanarak Arapça merkezli-usulcü yorumu temelden alt üst etmektedir. Bu meyanda "Bir gönle girmek" veya "gönül yapmak" gibi tabirlerle anlatılan ahlak veya "Sevmek için yeryüzüne geldik" ${ }^{27}$ şeklindeki ifadeleri aynı kapsamda değerlendirmek gerekir.

Yunus'un şiirinde ahlakın ibadetler için amaç olarak ifade edilmesi hiç kuşkusuz bir önceki bölümde kısmen değindiğimiz Tanrı’nın özneliğiyle ilgilidir. Buna bağlı olarak da İbnü'l-Arabî'de gördügümüz üzere, insanın mazhar-ı kâmil şeklinde düşünülmesi burada belirleyici bir rol oynamıştır. İnsan mazhar-1 kâmil ise Tanrı'nın amacının gerçekleşmesi insanın ahlaklı olmasına bağlıdır. Bu durumda ahlak insan için ibadetlerin maksadı demek iken Tanrı için de insandaki muradının gerçekleşmesinin zemini ahlak olacaktır.

Sonuç itibarıyla Yunus ahlakla ilgili görüşlerinde geleneksel tasavvufun yaklaşımını takip eder: Ahlak anlayışının temelini dünyanın değersizliği oluşturur, bunda kuşku yoktur. Bu meyanda zahitlik başta olmak üzere birçok konu dünyanın değersizliğini beyan ederken bu sayede insan yeryüzündeki kavgaları, çatışmaları ve ben-sen mücadelesini aşabilir. Yunus dinî hayatı bile ben-sen kavgasının yok ettiğini belirterek, "aradan çıkma" ahlakından söz eder. Bu ahlak aynı zamanda cömertlik, fedakarlık infak gibi temel konulara dayanır. Fakat bunlar daha alt düzey konular, daha kabul edilebilir meseleler olarak ortaya çıkar. Yunus "bir yoksulu giydirmek" veya "bir yetimi görmek" şeklinde özetlenebilecek düşüncesiyle dinî hayatta öteden beri kabul görebilecek davranışlardan söz eder. Öte yandan bütün bu ahlak, kibrin reddedilmesi ve her insana hürmet ile en ileri noktasına ulaşırken Yunus bize hikmet ile tevazu veya doğru bakmak ile anlamak arasındaki ilişkiyi de anlatır. Bunlar, tasavvufun başından beri dile getirdiği anlamak ile ahlak, akıl ile ahlaki hayat arasındaki ilişkiyi gösteren örneklerdir. Bununla beraber Yunus'un ahlak anlayışı en çok insan sevgisinde tebellür eder. Bu meyanda insan sevgisi gerçekte ahlakın ikinci sebebi veya kurucu unsuru olabilecek şekilde, bütün davranışları yöneten ana konudur. Yunus "yetmiş iki millete bir göz ile bakmak" derken ${ }^{28}$ insanlık sevgisini en ileri noktasına taşımış olur.

Yunus'un şiirlerinde ibadet ile ilgili hususlar da yer alır, namaz kılmak, zekât veya hac gibi ibadetlere atıflar vardır. Fakat bunları şiirin kurucu unsuru haline

27 “Ben gelmedüm da’vîyiçün benüm işüm seviyiçün”; bkz. Yunus Emre, Dîvân-ı İlâhiyât, 371.

28 "Yitmiş iki millete birligile bakmayan / Şer'ile evliyâsa hakîkatde ‘âsîdür”; bkz. Yunus Emre, Dîvân-ı İlâhiyât, 267. 
gelmeden zikrettiğini belki de önemli bir kısmının başka yazarlara ait olduğunu düşünebiliriz.

\section{Yunus'ta Tanrı, İnsan ve Aşk: Ezelden Ebede İnsanın Yolculuğu}

Yunus'un şiiri bir insan sorunu şiiridir. "İnsan kimdir?" şeklinde dile getirebileceğimiz bu soru cevabını marifetü'n-nefs, yani insanın bilinmesi ile tasavvufun yöntem ve riyazetinin sonucunda bulunmayacaktır; o, yöntem ve riyazet vesilesiyle Hakk'ın ihsanı olarak ortaya çıkacaktır. Bu yönüyle onun düşüncesinin ana unsurunu teşkil eden insanın ezelîliği sorunu gerçekte insan kimdir sorusunun ilk cevabı şeklinde kabul edilebilir. İnsan kimdir sorusu ezelî insan fikren bizi götürerek sorunun ehemmiyetini yeniden kavramayı sağlar. Çünkü ezelî insan dediğimizde birçok noktada kavram haritamız değişiklik arz eder.

“İnsanın ezelîliği” derken Yunus Emre’de neyi bulabiliriz? Ezel, dört unsurdan müteşekkil olmayan, yani zamana ve mekâna sığmayan bir varlık olarak insana bakmak demektir. "Ben kimim?" sorusuna ezeli düşünerek cevap vermek, bedenin ötesindeki hakikati, insanın hakikatini konuşmak demektir. Bu itibarla ezel, başlangıç, ebed ise sonla ilgilidir; fakat her ikisinin de ucu açıktır, yani ezel bir başlama noktası değil, sonsuzluk anlamına gelirken ebed de bitiş noktası değil, sonsuza giden yol demektir. O zaman Yunus Emre'nin insan telakkisinin uçları belirlenmiş oldu: başıyla sonu belirsiz bir insan telakkisi Yunus Emre'nin şiirlerinde işlenecektir. Böyle iken Yunus'un aşk telakkisinin de bir yönünü fark etmiş olacağız. Ancak böyle bir yolculukta aşk ortaya çıkabilir, ancak sonsuz bir yolculukta Tanrı insan ilişkisini aşk üzerinden düşünebiliriz. Bu yolculuğunda hamlık, pişmek, yanmak, kendinden geçmek olacaktır ve bütün bunlar aşkın halleridir. Mesela Yunus şöyle der:

\section{Kafdă̆l zerrem degül ay u güneş bana kul}

Aslum Hak'dur şek degül mürşiddür Kur'ân bana ${ }^{29}$

Kafdağı bütün mükevvenata karşılık gelen bir kavramdır. "Kafdağı zerrem değil” dediğinde Yunus'un müteal insan telakkisini fark ediyoruz. "Ay u Güneş bana kul" tabiri de bu anlamda yorumlanabilir. Bilindiği üzere, kadim dünya, gökyüzü ve göksel cisimler ile yeryüzünün ilişkisini göksel varlıkların "sebepler" olmasına dayandırmıştır. Pagan inançları bu anlayış üzerine kurulu idi. Dinler ile bu anlayış yıkılarak insan gök ve yerin varlık sebebi haline geldi. Bu durum insanın özgürleştirilmesi demektir. Yunus bunu daha ileriye taşıyarak "Ay ve Güneş bana kul!’ demektedir. Burada Serrâc'1n (ö. 378/988) ifadesini kullanırsak Yunus’un

29 Yunus Emre, Dîvân-ı Illâhiyât, 255. 
sözlerini "şatahât" sayabiliriz. ${ }^{30}$ Çünkü göksel varlıkların insana kul olması dinde karşıllı̆ını bulabileceğimiz bir düşünce değildir. Yunus için bu durum insanın ezelî doğasıyla ilgili bir şeydir. O halde mahlûkatın bize musahhar (amade) olmasıla mahlûkatın bize kul olması arasında ciddi bir seviye farkı vardır, daha ileri giderek bunu bir mahiyet farkı olarak da düşünebiliriz. Burada şunu hatırlamak gerekir: Yunus'un kendisine kul olmakla betimlediği ay ile güneş öteden beri insanların en çok taptıkları göksel cisimlerdir. Hz. İbrahim "Ben batanları sevmem" ${ }^{31}$ dediğinde dinin insanlık düşüncesini nasıl dönüştürdüğünü fark etmiştik; Yunus Emre'nin söylediği ise -bir benzetme değil ise- çok daha ileri bir düşünceyi dile getirmektedir. Bunun ardından söyledikleri konuyu biraz daha açıklar mahiyettedir:

Çün dosta gider yolum mülk-i ezeldür ilüm

Hak'dan söyler bu dilüm ne kul ne sultân bana ${ }^{32}$

Yunus'un şiirlerinde dost veya sevgili Allah olmalıdır, bunda tereddüt yoktur. İnsanın yolunun Allah'a gitmesi ise O'ndan geliyor olmasının sonucudur. Yunus burada Allah'tan gelmek ile Allah'a gitmek ilişkisini “mülk-i ezeldir ilim” diyerek açılar. İnsan yeryüzüne gelmiş olsa bile, gerçekte ezel mülkünde yaşamaktadır, ezelî doğasını korumaktadır, yolculuğu ezelden ebede doğru gitmektedir. Burada tasavvuf düşüncesinde belirleyici rol oynayan, özellikle aşkı anlatan eserlerde ana kavramlardan birisi olan "asıl vatan" fikrini görmekteyiz. İnsan asıl vatanından gelirken yeryüzündeki derdi ve özlemi de bu vatana duyduğu özlemden ibarettir. Yunus burada "Ben yeryüzülü değilim, benim yolum, şehrim, vatanım ezeldir" diyerek insan telakkisini ortaya koymaktadır. Şiirin devamında ise bu ezelîlik fikri daha güçlü bir şekilde işlenir:

Yogıdı bu bârigâh, varıdı ol pâdişâh

Yunus'un burada söylediği açıktır: "Allah vardı ve O'ndan başka bir şey yoktu” diye yorumlanması mümkün bir mısradır bu. Fakat bunun ardından söyledikleri yorum alanımızı daraltır, bizi yine başka bir yol takip etmeye icbar eder:

Âh bu 'sşk elinden âh derd oldı dermân bana ${ }^{33}$

Burada aşkın paradoksal hallerinden birisi ile karşılaşıyoruz: derdin derman olması. İnsanın derdi Allah, dermanı ise Allah’tır. İnsanın zihnine eşlik eden, dinî ve düşünce hayatını sevk eden şey aslında Tanrı'nın mutlak birliğinin idrakidir.

30 Ebû Nasr es-Serrâc et-Tûsî, el-Lüma', thk. Muhammed Edîb el-Câdir (Amman: Dâru'l-Feth, 1437/2016), 505-550.

31 el-En'âm, 6/76.

32 Yunus Emre, Dîvân-ı İlâhiyât, 255.

33 Yunus Emre, Dîvân-ı Illâhiyât, 256. 
İnsan ezelî olan doğası ile ezelî bir hakikati dert edinebiliyor, onu aynı zamanda derman sayarak, Allah ile ilişkisini bu ezel üzerinden tesis edebiliyor. İnsanın ezelî tabiatını ise şöyle anlatır:

Âdem yaratılmadın, can kalıba girmedin

Şeytan lanet olmadın, Arş idi sayvân bana ${ }^{34}$

Kelamcıların en ciddi sorunlarından birisi "Rahmân arşa istiva etti" tenzih ve teşbih açısından yorumu iken Yunus Emre arşı insanın yeri olarak kabul etmektedir. Bu düşüncenin bir benzerinin ise kalp ile arş arasında kurulan ilişki olduğunu hatırlamak gerekir. Sonra Yunus'taki ana kavram olan aşk ile ezel ilişkisini tesis etmek üzere şöyle der:

Evvel dahi varıdı cânumda bu 'ışk odı

Eşkere itmez idüm bilürdüm ki dost kodi ${ }^{36}$

"Evvel dahi var idi canımda bu aşk", yani aşk insanda dünyada ortaya çımış, insanın eliyle teşekkül etmiş bir hal değildir. Bu itibarla aşk yeryüzülü değildir. Allah ile insan arasındaki ezelî bağın ismi aşk olmaktadır, dolayısıyla aşk, müktesep, yani insanın kazandığı ve onun fiili olan bir iş değildir. Haddizatında aşkı insanın gönlüne yerleştiren ise Allah'ın kendisidir. Burada apriori bilgi mesabesinde zihnin bir bilgisi olarak aşkı düşünmemiz mümkündür. İnsan bu bilgiyi yaşadı̆̆g hayat içinde fark etmiş olsa bile, bunun öncesinde onun farkında olunmayan haller yaşanır: huysuzluk, çatışma vb. gibi haller, Ferîdüddin Attâr'ın (ö. 618/1221) da söylediği gibi, "insanın ezelî tabiatında meknuz olan bilginin tezahürleridir."

Aşk anadan doğmadl, kimseye kul olmad ${ }^{37}$

Yunus Emre, burada aşkı kendimize mal edebileceğimiz her ihtimale kapıyı kapatarak "Aşk doğmamıştır” demiştir. Demek ki aşk insanın ürünü veya emeği olmadığı gibi ezelî insandaki ezelî hal de aşktır.

Ezelde benim fikrim, Ene'l-Hak idi zikrim ${ }^{38}$

Burada fikir, aşk, ezel ilinde birleşerek Hak ile insan arasındaki ilişkiyi zirvesine taşımaktadır. Gerçekte aşk Tanrı ile insan arasındaki asıl-fer ilişkisinin neticesidir. Bu yönüyle aşk bu bölünme algısından ortaya çıkarken vuslat ise ikiliğin ortadan kalkarak tevhide dönmenin ta kendisidir. Burada dilin geçmiş zaman olarak

34 Yunus Emre, Dîvân-ı Illâhiyât, 256.

35 Tâ-Hâ, 20/5.

36 Yunus Emre, Dîvân-ı İlâhiyât, 512.

37 Yunus Emre, Dîvân-ı İlâhiyât, 512.

38 Yunus Emre, Dîvân-ı Illâhiyât, 512. 
kullanılması insanı aldatabilir, halbuki ezelin zamanı yoktur. İbnü'l-Arabî’ye göre naslarda Tanrı'ya dair kâne (idi, oldu) fiilinin kullanımının süreklilik bildirmesi gerekir; aynı şekilde zaman dışı olan ezel hakkındaki bütün ifadelerin de süreklilik bildirmesi gerekir. ${ }^{39}$ Ezel vardır, sürekli olan odur. İnsan ezelî ise o da süreklidir, her zaman olandır, her zaman olacak olandır. Ezelde bir ayrım olmadığına göre, Ene'l-Hak o tevhidi anlatabilecek yegâne ifadedir. O halde biz, insanın ezelîliği fikrinin cevabını bulduk, daha doğrusu ezelde kim olduğunun cevabı ortaya çıktı: İnsan ezelde Ene'l-Hak denilen bir hal üzere Tanrı ile birlik halindeydi.

\section{Henüz dahi doğmadan o Mansûr-ı Bă̆dâd $\imath^{40}$}

Bunun böyle olacağı bellidir, çünkü aşk anadan doğmamışken Ene'l-Hakk'1n Hallâc'dan öğrenilmesi mümkün olamaz. Burada tasavvuf tarihinde anane şeklindeki öğrenimin bir açmazı ile karşı karşıyayız, çünkü Hallâc doğmadan Ene'l-Hakk'1 öğrenmek mümkün ise o zaman düşünce sürekliliğinden söz etmek mümkün değildir. Bunun akabinde aşk hakkında söyledikleri aşkın başka yönlerine dikkatimizi çekse bile, bize yeni bilgi vermez. Mesela şöyle der:

Ezelî bu aşkı ben, bu mülke sürüp geldim ${ }^{41}$

“Aşk oradan, yani ezelden buraya geldi, benimle beraber geldi.” İnsan dünyaya o aşk bilgisiyle gelmiş, sonra yeryüzünden yine aşk ile çıkabilecektir. O zaman insanın hatırlaması gereken en önemli şey bu aşk olmalıdır. Bu kez Yunus'un tevhidi ve birliği tekrar ettiği başka bir mısra gelir.

Bir idim orda şeksiz, uş yine bile geldim ${ }^{42}$

Dinî hayat, tevhit üzerine kuruludur; fakat tasavvufta tevhit meselesi öteki dinî bilimlerin telakkisinden özünde ayrışır. Sûfîlere göre tevhidin birinci kademesi Tanrı'nın fiillerde birlenmesi iken bunun devamında başka mertebeler ortaya çıkar. Bunların hepsinin Yunus'ta bulunup bulunmadığını en azından bu şiir üzerinden tespit edemeyiz. Fakat burada tespit edebileceğimiz konu, insan ile tevhit ilişkisi olmalıdır. Tasavvufa göre Tanrı'nın birlenmesi tevhidin doğru anlatımı değildir. Tanrı zaten birdir. Tevhidi anlayabilmek için insanın birliğini konuşmamız gerekir. Bu tabir Cüneyd-i Bağdâdî'den (ö. 297/909) beri gelen bir kavramlaştırmadır. ${ }^{43}$ İbnü'l-Arabî ise eserinin en önemli kısmını insanın ferdiyeti üzerine kurarak

39 Muhyiddîn İbnü'l-Arabî, Fusûsu'l-Hikem, trc. Ekrem Demirli (İstanbul: Kabalcı Yayınları, 2006), 208-210.

40 Yunus Emre, Dîvân-ı İlâhiyât, 512.

41 Yunus Emre, Dîvân-ı İlâhiyât, 370.

42 Yunus Emre, Dîvân-ı Illâhiyât, 370.

43 Cüneyd'in "Kitâbü'l-Mîsâk" ve "Kitâbü'l-Fenâ" başlıkl1 eserleri için bkz. Su'âd el-Hakîm, Tâcü’l- 'ârifin el-Cüneyd el-Bağdâdî (Kahire: Dâru'ş-Şurûk, 1426/2005), 229-260. 
Cüneyd'den beri gelen düşünceyi en ileri noktaya taşımış oldu. ${ }^{44} \mathrm{Bu}$ durumda insanın bir olması tevhidi idrakin esas konusudur. Bu birlik ise yetkinleşme ile aynı anlama gelerek ahlaklanmanın sebebini ortaya çıkartır. İnsanın yetkinleşmesi ahlaklanmasıyla mümkün ise tevhide giden yol da ahlaktan geçmelidir.

Ezel benim ilimdir, Elest benim yolumdur ${ }^{45}$

Burada Yunus'un sözleri belirsizleşir, daha doğrusu başka bir kavram ile birleşerek düşünce ilk gücünü yitirir. Gerçekte "Elest” ezel anlamına gelmemelidir; bedenden önceki varlığa atıf yapıyor olsa bile, elest âlemi en azından vahdet-i vücûd telakkisine göre ezel âlemi olmayabilir. Elest’ten ezele gidilir; ama ezel, elest değildir. Öyle anlaş11ıyor ki Yunus Emre elest ile ezeli birbirine karıştırır.

Et ve deri büründüm, geldim size göründüm

Adımı âdem kodum, ondan zuhura geldim ${ }^{46}$

Burada şiir neticeye ulaşmakta, Yunus'un öteki insanlarla ilişkisi kadar kendi yolculuğunu anlatışı bir noktaya varmaktadır.

Aşktan dertli olana, dermanım vardır benim

Aşk sayrısı olana, erkandır sora geldim ${ }^{47}$

Böylece Yunus bize insanın ezelî yolculuğunun bir kısmını anlatarak herkesi aşk meselesini konuşmaya, onun erkanını bilenlere aşkı sormaya geldiğini söylemektedir. Yunus'un dünya telakkisi de bu cümle ile özetlenebileceği gibi bütün insanları bir görmesinin nedeni de ortaya çıkmaktadır: İnsan ezelî bir yolcudur, ezel ilinden gelen, ezele giden bir yolcu olarak bütün insanlar, en azından aşk üzerine konuşabilecek olanlar onun yoldaşı olacaktır.

\section{Sonuç}

Yunus Emre'nin şiiri tasavvufun temel özellikleri sayabileceğimiz belli başl1 alanlardaki kurucu niteliklerini barındıran bir şiirdir. Bu itibarla birçok yönden geleneksel tasavvufun kavram ve dilini yeni bir şekilde kendi şiirine taşımış, geçmiş tasavvufun özellikle de bazı büyük sûfîlerin izleri onun şiirine yansımıştır. Hallâc-1 Mansûr gibi büyük sûfîlerin şathiye sayılan sözleri kadar Peygamber sevgisinin en ince anlatımları onun şiirinde geniş bir anlatı imkânı sunar. Bu meyanda onun şiirinde dikkatimizi ilk çekebilecek husus, bütün şiirin aşk üzerine kurulu olmasıdır.

44 İbnü'l-Arabî, Fusûsu'l-Hikem, 235-247.

45 Yunus Emre, Dîvân-ı İlâhiyât, 370.

46 Yunus Emre, Dîvân-ı İlâhiyât, 370.

47 Yunus Emre, Dîvân-ı Illâhiyât, 371. 
Öyle ki Yunus'un şiirlerinde aşk her şeyin kendisine vardığ ana temayı teşkil eder. Bu da anlaşı1ır bir durumdur, çünkü bir şiirin aşk üzerine kurulu olması Tanrı telakkisindeki bir değişimi gösterdiği kadar buna bağlı olarak başka birkaç temanın da temelden değişmesini iktiza eder.

Yunus'un şiirini ortaya çıkartan en önemli nedenlerden birisi yaklaşık dört beş asırda İslam toplumunda Tanrı telakkisi üzerinde ortaya çıkan büyük değişimdir. Müslüman toplumun dindarlık anlayışının şekillenmesiyle birlikte dikkatler yasaya verilerek Tanrı ile irtibat öte dünyaya bırakılmış, günlük hayat içinde bir Müslüman dua ve benzeri yollarla Tanrı ile irtibat kursa bile gerçek karşılaşmanın ahirette olacağı inancı yerleşmiştir. Sûfîler bunu reddederek Tanrı ile "burada ve şimdi" olan irtibat üzere dindarlığı ileri bir noktaya taşımayı hedeflediler. Bu büyük bir değişimdi; özellikle sûfîlerin vecd anlayışları Tanrı'nın burada bulunmuşluğu üzerine kuruluydu. Tanrı'yı burada bulmanın neticesi ne olacaktır? Hiç kuşkusuz, böyle bir telakkide rıza kavramı büyük bir sevgiye dönüşerek aşk merkezli dinî hayatı ortaya çıkarmıştır. Aşk, Tanrı ile insan arasındaki ilişkiyi bir süreklilik ve asıl-fer ilişkisi şeklinde düşünmenin sonucudur. Burada insan seven iken Tanrı maşuk, yani sevilendir. Aşkın halleri olan özlemek, uzaklık, hicret gibi kavramlar Yunus'un şiirlerini şekillendirirken gerçekte bütün hayat Tanrı'ya doğru bir yolculuk üzerine kurulur. Bununla birlikte esas büyük değişim maşukun gerçek âşı olarak tecelli edişiyle gerçekleşir, orada insan her şeyiyle Tanrı'ya muhtaç bir kul olduğunu idrak ederek tasavvuf maksadına ulaşmış olur.

Öte yandan Yunus'un şiiri nübüvvet ve hadis alanındaki bir değişimi de beraberinde getirir. Bunu sünnet merkezli ibadet hayatının yerini ahlakın alması olarak ifade edebiliriz. Yunus'un düşüncesi aşk ile ahlak arasında bir bağ kurunca ahlak anlayışı geleneksel dindarlığın kalıplarını aşarak daha takip edilemez bir hale gelmiştir. Bu meyanda ahlakın bir ölçüsü olmadığ kadar gerçekte bir tanımı da kalmaz; ahlakın bizi nereye götüreceğini de bilmiyoruz. Onun düşüncesinde ahlak insanın içinde kendi benliğinin de olduğu her şeyi bırakmasının yoludur. $\mathrm{Bu}$ anlayışın akabinde ise Yunus insan telakkisine ulaşır. Yunus'ta insan ezelî varlıktır, daha doğrusu insanın ezelîliği onun düşüncesinde merkezî bir yer tutar. Bu meyanda insanın beden öncesinde bir hakikat sahibi olması, başta aşk olmak üzere her şeyin nedeni olarak görülebilir. Yunus'un bir şiiri bu ezelî insan fikrini izah ederken aynı zamanda buna bağlı birçok konu da dolaylı bir şekilde ele alınmış olur. Yunus'un etkileri üzerinde daha çok araştırmalar yapılmalıdır. Yeni araştırmalarla Yunus'un düşüncesinin kaynakları kadar düşüncesinin günümüz için ifade edebileceği anlamı da daha iyi göreceğiz. 
Hakem Değerlendirmesi: Dış bağımsız.

Çıkar Çatışması: Yazar çıkar çatışması bildirmemiştir.

Finansal Destek: Yazar bu çalışma için finansal destek almadığını beyan etmiştir.

Peer-review: Externally peer-reviewed.

Conflict of Interest: The author has no conflict of interest to declare.

Grant Support: The author declared that this study has received no grant support.

\section{Kaynakça/References}

Attâr, Ferîdüddin. Evliya Tezkireleri. haz. Süleyman Uludağ. İstanbul: Kabalcı Yayınları, 2007.

Aziz Mahmûd Hüdâyî. Âlemin Yaratılışı ve Hazreti Muhammed'in Zuhuru. trc. Kerim Kara-Mustafa Özdemir. İstanbul: İnsan Yayınları, 1997.

el-Belâzürî, Ebü'l-Abbâs Ahmed b. Yahyâ. Ensâbü'l-Eşrâf. thk. Riyâz ez-Ziriklî-Süheyl Zekkâr. 13 Cilt. Beyrut: Dâru'l-Fikr, 1417/1996.

Demirli, Ekrem. İslam Metafiziğinde Tanrı ve İnsan. İstanbul: Kabalcı Yayınları, 2009.

Demirli, Ekrem. "Varlık Olmak Bakımından Varlık İfadesinin Sûfîlerce Yeniden Yorumlanması ve Bu Yorumun Metafizik Sonuçları”. İslâm Araştırmaları Dergisi 18 (2007): 27-48.

Demirli, Ekrem. "Zahirî İlimlerin Otoritesi Karşısında Tasavvuf'un Meşruiyet Arayışı”. İstanbul Üniversitesi İlahiyat Fakültesi Dergisi [Darulfunun İlahiyat] 15 (2007): 219-244.

Düzdağ, Mehmet Ertuğrul. Şeyhülislâm Ebüssuîd Efendi Fetvaları Işığında 16. Asır Türk Hayatı. İstanbul: Enderun Kitabevi, 1983.

Gazzâlî, Ebû Hâmid. el-Münkıı mine 'ḍ-ḍalâl. nşr. Cemîl Salîbâ-Kâmil Ayyâd. Dımaşk: Matbû‘âtu Mektebetü’n-neşri'l-'Arabî,1358/1939.

el-Hakîm, Su'âd. Tâcü'l- 'ârifîn el-Cüneyd el-Bağdâdî. Kahire: Dâru’ş-Şurûk, 1426/2005.

Hallâc-1 Mansûr. Kitâbü'ț-Tavâsîn. nşr. Louis Massignon. Paris: Geuthner, 1913.

el-Hücvîrî, Ali b. Osman. Keşfü'l-mahcûb. nşr. Valentin Aleksiyeviç Jukovski. haz. Kâsım Ensârî. Tahran: Kitâbhâne-i Tahûrî, 1375hş./1996.

el-Hücvîrî, Ali b. Osman. Hakikat Bilgisi. trc. Süleyman Uludağ. İstanbul: Dergâh Yayınları, 2014.

İbn Hanbel, Ebû Abdullah Ahmed b. Muhammed eş-Şeybânî. el-Müsned. thk. Sidkî Muhammed Cemil Attâr. 10 cilt. Beyrut: Dâru'l-Fikr, 1991.

İbnü'l-Arabî, Muhyiddîn. Fusûsu'l-Hikem. trc. Ekrem Demirli. İstanbul: Kabalcı Yayınları, 2006.

İbnü'l-Arabî, Muhyiddîn. Fütûhât-ı Mekkiyye. trc. Ekrem Demirli. 18 Cilt. İstanbul: Litera Yayıncılık, 2006-2012.

el-Kelâbâzî, Ebû Bekir Muhammed b. İbrâhim. et-Ta 'arruf li-mežhebi ehli 't-tașavvuf. nşr. Ahmed Şemseddin. Beyrut: Dâru'l-Kütübi’l-İlmiyye, 1413/1993.

el-Kuşeyrî, Ebü'l-Kāsım Abdülkerîm b. Hevâzin. er-Risâletü'l-Kuşeyriyye. nşr. Enes Muhammed Adnân eş-Şerfâvî. Cidde: Dâru'l-Minhâc, 1438/2017.

es-Serrâc, Ebû Nasr et-Tûsî. el-Lüma ' thk. Muhammed Edîb el-Câdir. Amman: Dâru'l-Feth, 1437/2016.

Tatc1, Mustafa. “Âşık Yunus ve Başka Yunuslar”. İçinde Dîvân-ı İlâhiyât. mlf. Yunus Emre. 629-646.

3. Baskı. İstanbul: H Yayınları, 2014. 
Tatc1, Mustafa. "Yunus Emre'nin Hayat1, Sanat1 - Şiir Dünyası". İçinde Dîvân-ı İlâhiyât. mlf. Yunus Emre. 9-168. 3. Bask1. İstanbul: H Yayınları, 2014.

et-Tirmizî, Ebû Îsâ Muhammed b. Îsâ. el-Câmi 'ü'l-kebîr. thk. Beşşâr Avvâd Ma'rûf. 6 Cilt. Beyrut: Dâru'l-Garbi'l-İslâmî, 1996.

et-Tüsterî, Sehl b. Abdullah. Tefsîrü'l-Kur 'âni'l- 'aẓ̂m. nşr. Muhammed Bâsil Uyûn es-Sûd. Beyrut: Dâru'l-Kütübi'l-İlmiyye, 1428/2007.

Yunus Emre. Dîvân-ı İlâhiyât. haz. Mustafa Tatc1. 3. Baskı. İstanbul: H Yayınları, 2014. 